\title{
Erratum: Breed se bybelse pastorale model Skriftuurlik begrond in 2 Petrus 1:3-11: 'n Eksegetiese toeligting
}

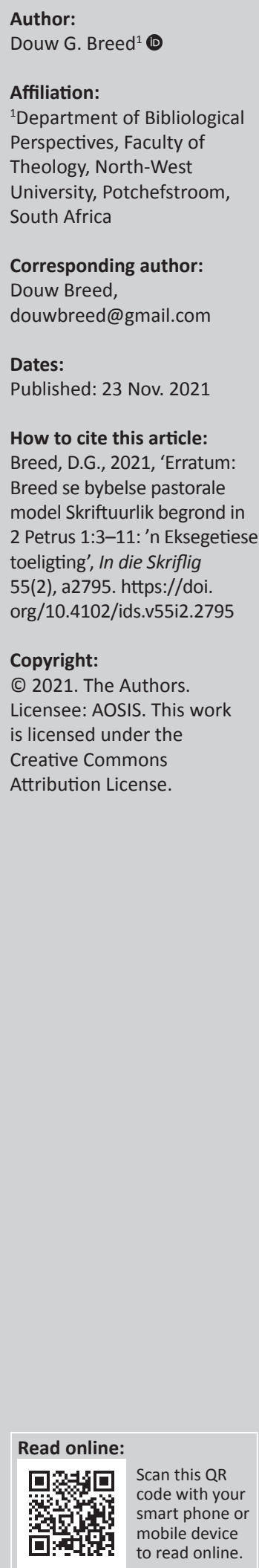

In the version of this article initially published, Breed, D.G., 2021, 'Breed se bybelse pastorale model Skriftuurlik begrond in 2 Petrus 1:3-11: 'n Eksegetiese toeligting', In die Skriflig 55(2), a2673. https://doi.org/10.4102/ids.v55i2.2673, the accepted date was given incorrectly. The correct acceptance date should be 21 Oct. 2020 instead of 21 Oct. 2021.

This correction does not alter the study's findings of significance or overall interpretation of the study results. The publisher for any inconvenience caused. 